\title{
MATERNIDADE, CULPA E RUMINAÇ̃̃O EM TEMPOS DIGITAIS
}

\author{
MOTHERHOOD, GUILT AND RIMINATION IN DIGITAL TIMES
}

\section{RESUMO}

Desde o século XVIII, o sentimento de culpa esteve tão atrelado à maternidade quanto os ideais de dedicação e amor. Recentemente, discussões sobre ela têm aumentado, sobretudo nos sites de redes sociais. São debates que buscam, entre outros objetivos, repensar valores tradicionalmente associados à atividade materna. $\mathrm{O}$ artigo explora as modificações históricas e subjetivas que permitiram que mulheres falassem sobre uma questão íntima (a maternidade) em um ambiente compartilhado. Para isso, analisa alguns comentários feitos por mães no site de rede social Facebook sobre suas vivências maternas, tomando por base os conceitos de ruminação de Nietzsche (século XIX) e de culpa de Freud (século XX). Ao acionar dois dos mais influentes pensadores modernos para refletir sobre manifestações contemporâneas, percebese que os discursos produzidos pelas mães procuram se afastar do sentimento de culpa materna, em um processo que se aproxima do que Nietzsche classifica como ruminação das experiências.

Palavras-chave: Maternidade. Culpa. Ruminação. Subjetividade Moderna. Subjetividade Contemporânea. Sites de Redes Sociais.

\section{ABSTRACT}

Since the eighteenth century, the feeling of guilt has been as tied to motherhood as the ideals of dedication and love. Recently, discussions concerning motherhood have increased, including on social network sites. These debates seek, among other goals, to rethink values traditionally associated with maternal activity. The article explores the historical and subjective changes that allowed women to talk about an intimate issue (motherhood) in a shared environment. To reach such goal, the paper analyzes some comments made by mothers on the social network site Facebook reporting their maternal experiences, based on the concepts of Nietzsche's rumination (19th century) and Freud's guilt (2oth century). By triggering two of the most influential modern thinkers to reflect on contemporary manifestations, it is perceived that the speeches produced by the mothers stray from the feeling of maternal guilt in a process that approaches what Nietzsche classifies as a rumination of experiences.

Keywords: Motherhood. Guilt. Rumination. Modern Subjectivity. Contemporary Subjectivity. Social Network Sites. 


\section{Introdução}

Discussões sobre a maternidade têm se tornado mais comuns não apenas na vida cotidiana, mas também em diferentes mídias ${ }^{1}$, com destaque para sites de redes sociais (SRSs) e, entre eles, o Facebook. A plataforma abriga dezenas de páginas voltadas para o que aqui se chama questão materna, ou seja, as práticas, disputas, valores e construções culturais, sociais e políticas em torno da maternidade. Conduzidas por mulheres - quase sempre mães -, proporcionam discussões cujo foco encontra-se nos desafios da atividade maternal e nos preconceitos que rodeiam tanto as mães quanto as mulheres que não desejam filhos. É o caso das páginas Senta que lá vem história, Uma mãe como você, Mãezice por Ananda Urias e Rotina de Mãe que, entre julho de 2017 e maio de 2018, publicaram textos que mobilizavam um sentimento em comum: a culpa presente na maternidade. As postagens² estão listadas abaixo.

I) Essa culpa não é sua - Mãezice por Ananda Urias, 18 de julho de 2017.

II) Mãe erra! - Uma mãe como você, 25 de agosto de 2017.

III) Espero o dia que eu vá rir de tudo isso - Rotina de Mãe, 7 de maio de 2018.

IV) SÓ BISERVANDO - Senta que lá vem história, 10 de maio de 2018.

Desde o último terço do século XVIII, no contexto ocidental, a culpa caracteriza um importante elemento da construção da figura materna, atuando também como recurso coercivo para que a mulher exerça uma maternidade a mais próxima possível da que é socialmente estabelecida como desejável - uma mãe que assume total ou maior parte da responsabilidade pelos filhos, devotada, amorosa, que oculta sentimentos conflitantes e se penaliza por seus erros (BADINTER, 2011). No entanto, apesar de reconhecerem a existência da culpa, as postagens se empenham em processar as frustrações maternais para que a mãe - no caso, tanto a autora da publicação quanto sua possível leitora - se afaste desse sentimento. Dinâmica semelhante ocorre nos comentários recebidos pelas postagens, feitos por mulheres que, partindo de suas experiências particulares, afirmam lidar com o mesmo problema em relação aos filhos e ao exercício do papel de mãe.

Tal exposição da vivência materna não seria possível até recentemente. Não apenas pela inexistência de dispositivos tecnológicos que a permitissem,

1 O programa Papo de Mãe (TV Cultura), a websérie Deu Positivo (Hysteria), o documentário Lugar de Mulher (GNT), a matéria Desconstruir a maternidade romântica é nosso papel (Géledes), o evento Ser Mãe não é Saber Tudo (Clube Quindim), entre outros.

2 "Essa culpa não é sua", disponível em: <https://www.facebook.com/maezice/photos/a.5154240519 55871.1073741828.515187031979573/787352381429702/?type=3\&theater>; "Mãe erra!", disponível em: $<$ https://www.facebook.com/umamaecomovoce/posts/1443067485742850>; "Espero o dia que eu vá rir de tudo isso", disponível em: <https://www.facebook.com/rotinademae/photos/a.1423382744544340. 1073741828.1421988724683742/2091949597687648/?type=3\&theater>; "SÓ BISERVANDO", disponível em: <https://www.facebook.com/sentaquevemhistoria/posts/1979543382080576>. Acessos em: 25 maio 2018. 
mas, sobretudo, por uma noção de subjetividade que difere da atual. Ao longo da modernidade, evitava-se que aspectos pertencentes à esfera íntima fossem compartilhados no espaço público. As subjetividades modernas se construíam de maneira internalizada, constituindo um núcleo denso, misterioso e essencial, no qual a culpa figurava no centro da articulação entre os desejos proibidos e a repressão encarnada pela lei e/ou pela moral do projeto civilizador. Por isso, Freud (2010) alertava para a necessidade de desconfiar do programa de felicidade desse mesmo projeto - com suas regras, costumes e leis -, pois estaria na base do malestar, sendo sua principal causa.

Atualmente, porém, percebe-se um deslocamento no eixo sobre o qual as subjetividades se edificam. Abandonam o espaço interiorizado para priorizar o aspecto físico, o comportamento visível e aquilo que o indivíduo exibe de si mesmo, ou seja, valorizam o que se vê. Paralelo a esse movimento, a vergonha passa a assumir um papel cada vez mais significativo na organização das experiências e na configuração das subjetividades contemporâneas, ocupando o lugar que antes pertencera à culpa (BEZERRA JUNIOR, 2017).

Nesse contexto em que o visível ganha tanta relevância, os SRSs - entre eles, o Facebook -apresentam-se como dispositivos de visibilidade nos quais os indivíduos constroem sua subjetividade, criando uma imagem de si que procura não apenas adequar-se ao meio em que é exposta, mas comunicar-se com aqueles que a veem. Trata-se, portanto, de uma subjetividade alterdirigida, na qual, conforme aponta 91 Paula Sibilia (2015; 2016), o que se busca é o reconhecimento do olhar alheio. Nesses sites, as reações provocadas por aquilo que se expõe também formam a identidade do sujeito (BRUNO, 2013; KING, 2016; HEARN, 2017). A participação de outros agentes além de si mesmo integra a construção subjetiva contemporânea.

Uma prática empregada para garanti-la é compartilhar informações e registros nos quais se exiba boa aparência, satisfação, conexões e/ou a realização de algo que o sujeito acredita que seus pares acharão importante ou interessante (SIBILIA, 2015; KING, 2016). Reduz-se, assim, o risco de ser ridicularizado, ignorado ou atacado, diminuindo, consequentemente, as chances de vexame em tais plataformas.

No entanto, não é isso que fazem as mulheres que compartilham aspectos difíceis e íntimos de suas experiências maternais. Pelo contrário, expõem detalhes que as tornam mais vulneráveis à desaprovação alheia, além de promoverem uma performance de si baseada em falhas e traços que geralmente são editados em prol de uma imagem pessoal mais atraente.

Amanda Santos e Paulo Vaz (2017) argumentam que os testemunhos de indivíduos no espaço público, inclusive nos SRSs, produzem uma nova subjetividade: a da vítima. Pensar a si próprio e sua trajetória de vida por meio da figura da vítima (alguém sob influência de ações que não controla) daria ao indivíduo que sofre uma explicação para seus sentimentos desagradáveis, de modo que consiga manter suas crenças e valores. Afinal, ao contrário da experiência da culpa moderna - que, nascida do atrito entre o desejo individual e a norma vigente, abria espaço para a reflexão internalizada -, a narrativa da vítima, por implicar a dinâmica da acusação, 
impede o indivíduo de se questionar sobre sua moralidade. A acusação fornece um culpado para o sofrimento, um lugar de imoralidade ao qual será possível direcionar sentimentos desagradáveis e eliminar a dor, já que a culpa configura-se como externa ao sujeito. Portanto, não lhe cabe refletir sobre seus atos, muito menos internalizar uma responsabilidade que não é dele.

Se, para Freud (2010), o homem ${ }^{3}$ civilizado é fruto de uma cultura que promove a culpa - e que, por sua vez, leva ao mal-estar - para Nietzsche (2009), o homem (no caso, os alemães, mas estendendo-se às demais nacionalidades capitalistas ocidentais) era tão grosseiro que precisou de torturas terríveis para adotar a civilidade na qual se reconhece. A lembrança dos castigos e da repreensão é o que estaria por trás da obediência e conformidade às normas civilizatórias estabelecidas.

A transformação do homem em ser cultural precisou de um regime da crueldade e implicava o risco de perder o impulso vital do querer, a potência. Tais crueldade e estupidez (do hábito, dos costumes, da moralidade) seriam justificáveis caso servissem a um movimento em outro sentido que não o da civilidade. Contudo, tornar o homem cultural foi um processo embrutecedor. Em vez de expor suas diferenças, os indivíduos se esforçam para serem parecidos com o "rebanho", seguirem as normas vigentes. A cultura é um trabalho do homem sobre si e, para tanto, faz uso da mnemotécnica técnica de produção da memória.

Tal processo consiste em usar a dor para marcar determinadas lembranças. Para Nietzsche (2009), em algum momento foi estabelecido que aquilo que machuca é o que fica marcado no "bicho homem". A alegria seria considerada muito leve, demasiado criança. Assim, as religiões e a própria moral são baseadas na crueldade. Por meio dela, é possível criar memória (de alguém, de uma cultura). Poder-se-ia medir o nível de esquecimento de um povo tendo como parâmetro a quantidade de crueldades por ele implementada ao longo de sua história. Quanto maior a crueldade empregada, menor a capacidade de esquecer.

Diante disso, Nietzsche torna-se o primeiro filósofo a priorizar o esquecimento sobre a memória (FRANCO FERRAZ, 2010). Afirma que não existe esperança, orgulho, felicidade ou presente sem ele. Viver seria inclusive esquecer a própria mortalidade, faz parte de estar vivo suspender a única certeza: a da finitude. Assim, esquecer seria uma atividade primordial, não consistindo em uma força inercial, mas plástica, modeladora, que impediria qualquer fixação capaz de tornar o sujeito refém das marcas do passado. Trata-se, como aponta Maria Cristina Franco Ferraz (2016), de incorporar certos elementos em detrimento de outros.

Nietzsche associa oato de esquecer ao de digerir, elegendo-o como a atividade mais espiritual do homem. Nesse processo, o indivíduo ultrapassa a dicotomia corpo/espírito. A digestão não seria o oposto da memória, mas uma liberação: o sujeito libera sua consciência, sobretudo em relação a aspectos como funções corporais básicas ou eventos que lhe aconteceram. Ao processar as experiências -

3 Optou-se por utilizar o termo "homem" para designar seres humanos organizados em sociedade visando manter a terminologia usada por Freud e Nietzsche em seus estudos, reflexo da forte influência patriarcal sobre a produção intelectual da época. 
ruminando-as - é possível, enfim, libertar-se delas e do ressentimento que causam. Esse movimento ocorreria de modo introvertido, através de uma subjetividade no interior do indivíduo, conforme concebida no século XIX. Nesse sentido, a memória é tomada como um entrave que suspende o esquecimento. Seria uma contrafaculdade agindo para restringir aquilo que é constitutivo da vida - ser capaz de esquecer. Quem tem dificuldade em utilizar tal aparelho inibidor não consegue se livrar de nada. Portanto, nunca está pronto para o novo. Sem digestão e esquecimento não haveria renovação, apenas repetição.

Trazendo esse panorama para os comentários recebidos pelas postagens das quatro páginas apresentadas no primeiro parágrafo, cabe questionar: as mulheres que relatam suas experiências maternais em dispositivos como o Facebook estão praticando o esquecimento? Afinal, trazem à luz experiências e informações que costumam ser omitidas por elas mesmas durante a vivência maternal, muitas vezes com ressentimento. Por outro lado, seria essa "exposição dos bastidores" uma forma de ruminação, alterdirigida, contemporânea? Para onde se deslocam a culpa e a vergonha nesse contexto?

Ao comparar a concepção de subjetividade dos séculos em que Nietzsche e Freud teceram seus mais importantes pensamentos - XIX e XX - com a construção subjetiva contemporânea e os valores que a permeiam, o artigo explora os deslocamentos que permitiram que debates acerca da maternidade fossem realizados no Facebook, e que processos podem derivar dessa prática.

\section{Considerações metodológicas: apresentando as narrativas pessoais analisadas}

Dentre o material produzido entre 2016 e 2018, levantado por dissertação ${ }^{4}$ em andamento, foram manualmente selecionadas publicações de páginas maternas no Facebook que mobilizassem o termo "culpa" ou abordassem o sentimento de alguma forma. Como o objetivo do artigo era recolher narrativas pessoais de diferentes mães sobre sua relação com a culpa (tão presente na construção da maternidade) e a possível ruminação de experiências (no caso, maternas), optou-se por utilizar tais páginas como fontes primárias devido ao engajamento por elas gerado, isto é, as interações e comentários em suas publicações, quase sempre do público feminino.

Feito isso, foi necessário definir de quais postagens sairiam as narrativas a serem investigadas no trabalho. Para tal, realizou-se análise exploratória da seção de comentários de todas as 12 publicações relativas a culpa encontradas, verificando quais possuíam relatos sobre a culpa oriunda da função de mãe. O princípio da triagem foi qualitativo, não considerando a quantidade de comentários em cada postagem, mas sim seu conteúdo. Ao final do processo, foram selecionadas como fontes para coleta

4 Desenvolvida no Programa de Pós-Graduação da Universidade Federal Fluminense. Ver mais em: <http://www.ppgcom.uff.br/corpodiscente.php>. Acesso em o8 jun. 2018. 
do corpus as postagens das páginas Mãezice por Ananda Urias, Uma mãe como você, Rotina de Mãe e Senta que lá vem história.

No texto intitulado "Essa culpa não é sua", Ananda Urias, criadora da página Mãezice por Ananda Urias, critica a noção de que o sentimento de culpa é inerente à atividade materna e encoraja as mães a se libertarem dele, visto que as faz sofrer. Todas as mães cometem erros, diz, e não é preciso se culparem por isso. O texto "Mãe erra!", escrito por Ana Luiza Saraiva, administradora da página Uma mãe como você, dialoga com esta última constatação ao afirmar: "Mãe é ser passível de fraquezas. Porque mãe também é ser humano, e assim como tal, tem defeitos e erra mesmo”. Em seguida, afirma que as mães são as que mais se culpabilizam quando falham e que, ao contrário dos filhos, não conseguem esquecer esses erros e permanecem se lamentando, em uma prática que identifica não apenas como equivocada, mas injusta. "Mãe também é gente", conclui, não deveria ser cobrada como alguém infalível. Já o texto "Espero o dia que eu vá rir de tudo isso”, postado na página Rotina de Mãe (que também possui perfil no Instagram) por sua criadora, Aysse Machado, consiste em um desabafo por não se sentir tão competente quanto as outras mães, sobretudo as de blogs de maternidade que, segundo Aysse, romantizam a criação dos filhos. Apesar de não utilizar o termo "culpa", o texto se articula em torno do cansaço e das frustrações maternas da autora diante de determinadas expectativas com a maternidade, o que faz as respostas que recebe identificarem seu sentimento como o de culpa - e, portanto, adequado à amostragem. O texto "SÓ BISERVANDO", escrito na página Senta que lá vem história (derivada do blog homônimo) por Lucinha Marinzek, sua administradora, também critica o retrato materno feito por "essas blogueiras de maternidade com posts lindos e politicamente corretos". O texto pede para que as mães "da vida real" não se cobrem a alcançar o padrão de maternidade de mães que contam com estrutura financeira e rede de apoio muito maiores do que as delas. "Você faz o que lhe é possível. Liberte-se", finaliza, deixando implícito que a libertação se refere aos sentimentos de cobrança e de culpa, correlação que é feita nos comentários que a postagem recebeu.

As quatro publicações compartilham o reconhecimento da culpa materna, ou seja, a culpa relacionada à atividade maternal. Outra semelhança é o fato de defenderem que as mães precisam superar esse sentimento para viverem uma maternidade mais saudável e satisfatória, o que pode ser interpretado como uma espécie de ruminação das experiências maternas desagradáveis. Assim, os comentários derivam de fontes cujas ideias e conteúdos são bem próximos, o que também aproxima o teor das respostas obtidas.

Ao todo, as postagens receberam 564 comentários. Para definir os que integrariam o estudo, aplicou-se o método de seleção de amostra intencional, em que são utilizados "critérios que derivam do problema de pesquisa, das caraterísticas do universo observado e das condições e métodos de observação e análise” (FRAGOSO et al., 2011: 78-79). Desse modo, foram selecionados comentários que: a) mobilizavam diretamente os termos "culpa", "esquecimento", "digestão" ou seus derivados - culpar, culpada, esquecer, processamento, entre outros; b) eram representativos do conteúdo geral dos comentários recebidos pela postagem à qual respondiam, isto é, abarcavam, 
com maior profundidade, as principais temáticas e sentimentos presentes entre eles; e c) abordavam as ideias de culpa, esquecimento e/ou ruminação, mesmo sem acionar tais termos. Os critérios de seleção objetivaram construir uma amostra enxuta, que representasse o teor e a abordagem geral dos comentários recebidos.

A amostra, então, foi composta por 15 comentários: seis derivados da postagem "Essa culpa não é sua”; cinco da publicação "Mãe erra!"; um da "Espero o dia que eu vá rir de tudo isso" e três da "SÓ BISERVANDO". Para preservar o anonimato das autoras, seus nomes foram substituídos por letras.

\section{ESSA CULPA NÃO É SUA}

M.G.: Ananda, vc é uma poetiza que admiro muito e sempre que posso tô passando e lendo seus textos, e esse 'sempre que posso' é quando a culpa está demais, o sentimento de estar fracassando está tomando conta e o desespero de estar fazendo tudo errado me invade. Vc é uma inspiração verdadeira pra muitas mamães que estão em busca do acerto e que vez ou outra escorregam e cometem erros. Obrigada pela sua sinceridade, pelos lindos textos e, principalmente, por nos fazer acreditar que nós não estamos sozinhas nessa árdua caminhada.

R.V.U.: Esqueci de levar o maiô pra minha filha e hoje é dia de piscina... fiquei arrasada... foi bom ler esse texto... fiquei com ela até tarde ontem pq ela queria me contar tudo sobre o seu dia e brincar um pouquinho, depois tive insônia e fui dormir quase 2 da manhã com a cabeça cheia de preocupações e planos, perdi a aula que começava às 8 ... enfim, esqueci.

S.X.: Por essas coisas não me sinto culpada não, me sinto culpada quando lembro que poderia ter tido mais paciência, ter dado mais colo, mais abraços e ter evitado umas palmadas por motivos bobos, não que eu seja contra palmadas, mas tem que ter um motivo forte.

L.L.: Pura verdade. O pior é que além da inevitável culpa que nós mães sentimos ainda temos que lidar com palpites ou pior, comentários maldosos de quem acha que é perfeita. A perfeição não existe pra ninguém, melhor admitir fraquezas e buscar melhorar do que fingir ser o que não é.

I.R.: Euuuuu....nossa q alívio esse sentimento tão chato não é só meu, essa cobrança não acontece só comigo.

A.W.: Ótima leitura! Tenho um filho de 35 anos, e outro de 32. Até hoje tenho sentimento de culpa qdo não me sinto "100\%" mãe.

\section{MÃE ERRA!}

C.N.: Q isso!!!! esse texto....fazemos td isso!!! e ainda deixamos de fzr alguma coisa....pq quando nossos filhos erram nos culpamos...e nos perguntamos: onde errei? mas ....somos humanos...

M.S.: Verdade, damos nossas vidas por nossos filhos, mas depois crescem e esquecem que têm mãe, não fazem nem metade do que fizemos por eles. 
S.O.: Ser mãe é como viver um julgamento: é vc que não olha, é vc que não dá educação, é por tua causa que ele é o que é, mas ninguém vê que, depois que cresce, cada cabeça é uma sentença. T.V.: Acho que nunca tive tempo de ser mãe dessa maneira. Agora vejo, infelizmente.

T.A.: Realmente, eu só queria poder ser gente às vezes, além de ser mãe.

\section{ESPERO O DIA QUE EU VÁ RIR DE TUDO ISSO}

A.R.: Não se culpe, eu também ando cansada e olha que estou com 2....Queria poder tomar banho demorado sem medo do bb chorar, queria dormir cedo de barriga pra baixo, mas estou assistindo D.P.A com o $\mathrm{V}^{* * * * * * *}$ e dando mamá pro $\mathrm{E}^{* * *}$ e provavelmente esta noite vai ser longa...Queria arrumar meu cabelo que cresceu 5 dedos metade enrolada e metade lisa kkkk, mas estou cansada ...passo o dia todo arrumando a casa, limpando bb, ensinando o maior a ler, mas estou cansada....Mas mesmo assim, como vc disse, não estou reclamando, sempre quis dois filhos e amo eles demais, sem escolher nenhum predileto porque amo os dois por igual.... Mas estou cansada. Obs: E mesmo tão cansada de tudo agradeço a Deus todos os dias por ter eles comigo aqui.

\section{SÓ BISERVANDO}

S.C.B.: Eu trabalho meio horário, de 8 às 14. Minha mãe, santa, fica com meu filho pra eu trabalhar. Ele tem 1 a e $3 \mathrm{~m}$. Chego e pego ele às 14:30. Vou pra casa e aí é: dá fruta, brinca, arruma casa, dá colo, dá banho, faz a janta, dá janta pro bebê, lava roupa, recolhe roupa, faz compra, colo, colo, colo... se eu não tiver uma tv ou celular pra distrair o menino, ninguém come na casa, todo mundo anda com roupa suja, entre outros perrengues. Meu filho vê tv sim, na hora das refeições sempre no prato dele tem legumes, proteína e tudo que é saudável, mas às vezes rola um biscoito maizena, uma batatinha frita e um iogurte. Ou é isso ou é fome, porque não dá tempo de fazer o legume orgânico no vapor de água filtrada no filtro de barro. Sou uma "péssima" mãe, eu sei. Mas me libertei, faço o melhor que eu posso.

M.M.: A pregação da comida saudável, não gritar, não bater.... Eu concordo com tudo isso, mas do jeitinho que vc falou.... Todo dia n dá migs, a gente tenta... E tenta mto, mas somos humanas e nos virando sozinhas, né? Tem aquela hora que sempre chega em que a gente perde as estribeiras.... Se sente mal, culpada, aff!!! Mas é a vida, não somos perfeitas. Deixei de seguir mtas [blogueiras] tbm. C.F.: Onde clico para curtir mil vezes? Te amo Lucinha, porque quando estou me sentindo a pior mãe do mundo, quando perco a paciência com a cria e grito, brigo e logo depois me sinto culpada e menos mãe, vem vc com seus textos e me faz sentir gente novamente. 
A partir de então, exploram-se tais narrativas visando entender o quanto se aproximam dos conceitos de ruminação e culpa defendidos por Nietzsche e Freud.

\section{Subjetividade: da moderna à contemporânea}

Nas sociedades tradicionais, totalizantes, o indivíduo vale menos do que a organização social como um todo. Tornar-se alguém é encontrar seu lugar em uma hierarquia que já possui espaços alocados para que os indivíduos neles se encaixem. $\mathrm{O}$ que começa com a modernidade é a ideia de que o indivíduo - e não a sociedade - é o valor que deve prevalecer. Isso produz processos de subjetivação bastante diferentes. O indivíduo que, no mundo tradicional, se torna alguém ao descobrir qual é o seu lugar numa estrutura cujas posições são pré-determinadas passa, como indivíduo moderno, a ter que encontrar e construir seu próprio destino. Ele já não se funda na totalidade daquilo que o mito e a religião trazem - tem que se autofundar. Tal mudança conduz à possibilidade da revolução burguesa, à ideia de democracia, revolução proletária, movimentos feministas, entre outros desdobramentos (BEZERRA JUNIOR, 2014).

Essa nova conjuntura altera o modo como o indivíduo se constitui e se reconhece como um "eu". Nas regras de socialização tradicionais, o destino dos indivíduos está traçado de antemão, governado por instâncias que transcendem as deliberações individuais. $\mathrm{O}$ mundo moderno rompe com essa crença e cria outro tipo de sujeito. Alguém que continua sendo determinado, mas, ao contrário do homem tradicional que sabe o que o determina (deuses, Deus), o homem moderno, que destronou a onipotência dos deuses, não sabe ao certo o que o governa (ibid). Sente que há coisas nele que o dominam sem que ele saiba o motivo - o que o Romantismo denomina "paixões” (para Freud, "pulsões"; para Nietzsche, "descargas do querer"). O homem moderno é alguém que se vê livre para agir, mas, enquanto possui e constrói seu destino, também se vê despossuído de si próprio, pois a paixão irrompe como um impulso intenso que o domina. Tal cenário permite o surgimento do psiquismo e da psicanálise.

Ainda assim, existe um mundo que lhe é externo, a cujas regras o sujeito deve se adequar. Para Freud, "a liberdade individual não é um bem cultural” (2010: 57). A civilização nunca visou a liberdade, apesar de muitas delas, sobretudo ocidentais, terem sido construídas sob o discurso libertário. Graças ao que chama de evolução cultural, a liberdade experimenta restrições - e a justiça pede que ninguém escape a elas. Tal evolução surge como um processo peculiar que se desenvolve na humanidade, movida, por sua vez, à força (Trieb), ou seja, pela pulsão de agressividade e autodestrutividade inerente aos indivíduos. Em paralelo, tem-se a sublimação do instinto. Na visão de Freud, sublimar seria cercear potências em vez de elevá-las. Não seria positivo, e sim problemático. $\mathrm{O}$ homem estabeleceu determinadas instâncias (leis, moral, costumes) para se afastar dos instintos que sublima - ainda presentes e que precisam ser controlados. 
Assim, os recursos e estratégias para garantir a proteção da maioria não necessariamenteasseguram uma felicidade maior para o homem. Apesar de necessária, a sublimação do instinto gera problemas. "Não é fácil compreender como se torna possível privar um instinto de satisfação", diz o psicanalista (2010: 6o). No entanto, esse processo já se encontra naturalizado. Há sempre alguma instância de poder à qual o indivíduo será submetido em prol da convivência em sociedade. Nos séculos XIX e $\mathrm{XX}$, o decoro e a discrição operavam como mecanismos de controle extremamente eficazes, cujos protocolos discerniam de modo radical o que se podia fazer, dizer e mostrar no espaço público e na esfera íntima (SIBILIA, 2015).

Desse modo, o indivíduo podia desempenhar os papéis que lhe convinham na estrutura social vigente tendo no espaço privado a possibilidade de ser autêntico, revelar-se de maneira desvinculada às amarras e convenções sociais impostas. Acreditava-se que o "eu" verdadeiro, ou seja, a essência do sujeito, encontrava-se oculta e protegida em seu interior, sendo acessada apenas por meio de processos intimistas, como a escrita de diários (SIBILIA, 2016). Essa essência do sujeito era tomada como mais valiosa e determinante do que tudo aquilo visível sobre ele: roupas, aparência, sua imagem de forma geral.

Até meados do século XX, a moral burguesa pregava que os questionamentos, dores, pequenas alegrias e confissões fossem feitos no âmbito privado. Sua expansão para a esfera pública era considerada inadequada, vexatória, deselegante ou mesmo exibicionista. Já no século XXI, esses pudores mostram-se antiquados. Exibir a própria vida e seus feitos para terceiros, em ambientes coletivos, libertou-se de boa parte de suas conotações pejorativas para se converter em um gesto cada vez mais comum e até mesmo necessário.

Giorgio Agamben (2009) afirma que diferentes dispositivos geram diferentes processos de subjetivação. Os SRSs, a proliferação de câmeras e telas (que permitem se ver e se mostrar) e as tecnologias de comunicação (sobretudo audiovisuais e interativas) hoje são meios pelos quais os indivíduos compartilham experiências, opiniões, imagens, vídeos e narrativas como as voltadas para a culpa materna, em que se efetuam os processos de subjetivação contemporâneos. Nesse ambiente cada vez mais midiatizado, a subjetividade se constrói para e sob o olhar do outro, desejosa de sua aprovação e reconhecimento. Por mais que autores como Beatriz Polivanov (2014) demonstrem que a visibilidade não é o único motivo pelo qual se utilizam SRSs, o desempenho visível e a imagem pessoal de cada um ainda constituem valores importantes, proporcionando nos indivíduos o desenvolvimento da habilidade de se autopromoverem (BRUNO, 2013; KING, 2016; HEARN, 2017). O que se é deve ser visto, e assume-se que cada um seja aquilo que mostra de si mesmo.

As narrativas maternais que compõem a amostra figuram na seção de comentários de postagens feitas em modo público, visíveis para qualquer um que acesse seus links. Expõem aspectos da vida privada das mães que a escrevem, inclusive sentimentos e atitudes que, em suas próprias palavras, poderiam classificá-las como "péssimas mães". Se, por um lado, a publicação desses comentários expositivos confirma a prática contemporânea de levar vivências particulares para ambientes 
compartilhados, por outro revela que mostrar-se como mais interessante ou bemsucedido não é necessariamente o objetivo principal dessa iniciativa. Ao exporem suas rotinas atribuladas e a dificuldade para dar conta de todos os cuidados com os filhos e consigo mesmas, as autoras parecem buscar amparo e identificação. Nas palavras de I.R.: "nossa que alívio [ver que] esse sentimento tão chato não é só meu". O comentário de M.G., agradecendo pela postagem do texto "Mãe erra!", corrobora esta hipótese, visto que informa ler as publicações da página toda vez que "a culpa está demais (...) e o desespero de estar fazendo tudo errado me invade". Em seguida, diz que a autora é uma inspiração para mães "em busca do acerto e que vez ou outra escorregam e cometem erros". De modo semelhante, C.F. conta que, quando se sente "a pior mãe do mundo", os textos da página Senta que vem história a fazem se "sentir gente novamente”. A criação de uma rede de apoio para validar a forma como conduzem a maternidade e ajudá-las a superar seus obstáculos aparece enquanto motivação por trás do compartilhamento das narrativas, aproximando-se do que Polivanov (2014) afirma sobre os SRSs serem espaços que permitem diferentes tipos de socialização.

Na sociedade disciplinar descrita por Michel Foucault (1983), baseada no dispositivo do panóptico, criava-se um controle psicológico em que os indivíduos se autorregulavam e fiscalizavam, por acreditarem estar sendo vigiados pelas instituições de poder (ou que havia essa possibilidade). Os mecanismos de vigilância provocavam a interiorização da culpa pelo indivíduo, por ter se desviado das normas. Já no cenário atual, tais controle e vigilância são exercidos não apenas pelas regras de funcionamento de cada uma das tecnologias em que o sujeito expõe e constrói sua imagem, mas por cada um dos usuários dessas mesmas redes (BRUNO, 2013). Ou seja, ao mesmo tempo em que exibe seus feitos e identidade nas telas, o indivíduo também é exposto aos feitos e subjetividades alheios, os quais ele pode, de certa forma, regular: denunciando uma postagem que ache inadequada, compartilhando publicações que julgue interessantes ou mesmo bloqueando o perfil de determinados usuários. Sobretudo, é possível que avalie as construções subjetivas que recebe, tornando essa avaliação visível aos demais por meio de suas reações (ou falta de reações) a elas. Assim, a subjetividade contemporânea é construída tanto pelos e nos conteúdos que o indivíduo expõe de si mesmo em espaços compartilhados quanto pelo que o olhar alheio permite e/ou está disposto a ver dela. No caso das mães envolvidas nos comentários, o que suas narrativas dizem sobre si e o modo como maternam.

\section{Culpa e maternidade}

Na França do século XVIII, a partir da divulgação do Segundo Discurso de Jean-Jacques Rousseau (1754), são muitas as publicações que recomendam que as mães cuidem pessoalmente dos filhos, enfatizando também a necessidade da amamentação. Passam a impor à mulher a obrigação de ser mãe como prioridade, justificando-a por meio de teorias que sustentam o que Elisabeth Badinter (1985) 
chama de mito: o instinto materno, o amor espontâneo de toda mãe pelo filho. Esse amor passa a ser exaltado como natural e social, necessário para a manutenção da espécie e da sociedade. A associação dos termos "materno" e "amor" desloca a figura da mãe do lugar de autoridade para o âmbito do afeto e do carinho. Em contrapartida, o "mau exercício materno" passa a ser associado aos sentimentos de culpa, infelicidade e inadequação.

Tal movimento teve como precursor a queda do Antigo Regime, que fez com que a preocupação do Estado não fosse mais formar súditos dóceis para Vossa Majestade, mas produzir cidadãos que seriam a riqueza do país. Assim, a alta taxa de mortalidade infantil - em muito devida ao descaso com o qual as crianças eram tratadas - passa a ser combatida. Interessa ao Estado que o maior número possível de crianças nascidas no país sobreviva, para que se tornem adultos capazes de gerar dinheiro, conhecimento e demais insumos à nação. Como o período de maior mortalidade era a primeira etapa da vida, foi preciso convencer as mães a se aplicarem às esquecidas tarefas de amamentar, tratar e zelar por seus bebês. A partir disso, muitas mulheres perceberam que, ao incorporar seu papel de mãe devotada e carinhosa, alcançariam uma importância que jamais haviam tido na sociedade da época. Julgavam conquistar o direito ao respeito dos homens, o reconhecimento de sua utilidade e especificidade, já que apenas elas eram capazes de realizar uma tarefa que o homem não podia, ou não queria, assumir (BADINTER, 1985).

No Brasil do final do século XIX, a ação médica sobre a família projetou nas mulheres "a nobreza da função amamentar" (COSTA, 1999: 261), também visando a diminuição da mortalidade infantil, mas para concretizar o projeto progressista republicano. A medicina social, então, atuou para modificar a conduta física, moral e sexual da família burguesa citadina, com foco na orientação do papel da mulhermãe, colocada como responsável pela sobrevivência e instrução das futuras gerações brasileiras. Implementaram-se as ideologias da culpa, do devotamento e do sacrifício, relacionadas à condição materna.

O silenciamento diante das dificuldades maternais foi prática recorrente, sob a justificativa de que seriam suprimidas pelo sentimento de amor aos filhos. O próprio Freud (1976) estabelece que a mãe é o primeiro objeto amoroso do bebê, com o qual possui vínculo muito forte. Para o psicanalista, a feminilidade só é estabelecida quando o "desejo do pênis" que marca o crescimento das meninas pode ser substituído pelo desejo de um bebê. Ou seja, a maternidade seria uma compensação para sua "falta" fálica.

Somam-se a esse contexto as exigências de decoro e discrição pregadas durante a era moderna, que restringiam a fala sobre as experiências maternais particulares às paredes do lar. A maternidade, quando abordada no espaço público, aparecia como pauta de colunas e revistas femininas voltadas à instrução das mães, ou enquanto atividade pela qual algumas mulheres justificavam suas reivindicações sociais (FREIRE, 2009). Até a metade do século XX, conflitos e dúvidas presentes na rotina materna só eram conversados entre mulheres casadas - conforme demonstra Joana Maria Pedro (1998) -, ao contrário da atual ampliação dessa rede de trocas. 
Apesar disso, antigas práticas como a cobrança para ser uma mãe infalível, o julgamento sobre as formas de maternar e a culpa causada por escolhas que interfiram no bem-estar dos filhos continuam presentes. Se as mulheres conquistaram mais espaços e possibilidades, essa ampliação recai na forma de possíveis falhas em seu bom desempenho materno. Como explica Badinter, em entrevista ao site Delas:

Há 30 anos a vulgarização abusiva da psicanálise engendrou a ideia de que a felicidade, a inteligência e o desabrochar da criança portanto, o equilíbrio dela no futuro - dependem essencialmente do comportamento da mãe. Desde então, os ecologistas e outros adoradores da natureza contribuíram para que essa crença realmente existisse: de que para ser uma boa mãe, preocupada com a saúde do filho, é necessário amamentá-lo 24 horas por dia. E, de preferência, se devotar inteiramente a ele durante um ou dois anos. O resultado: as mães que não querem se conformar com essas diretrizes são cada vez mais consideradas mães indignas, e suas amigas as olham com suspeita. Com o passar dos anos, de fato, acabamos acrescentando uma tonelada de culpa nos ombros maternais (apud LOSSO, 2011).

Identifica-se o reconhecimento dessa culpa nas narrativas analisadas. Praticamente todas as autoras se dizem culpadas a respeito da forma como administram a maternidade. A.W. inclusive afirma que, mesmo com os filhos já adultos, continua tendo culpa ao não se sentir "10o\% mãe". Nota-se também o sofrimento que revelam nos relatos. A junção entre culpabilização e maternidade frequentemente as faz se autodepreciar por não conseguirem "ter mais paciência" (S.V.) ou "fazer o legume orgânico no vapor de água filtrada no filtro de barro" (S.C.B.), a ponto de se sentirem "menos mães" (C.F.). Já a sensação de serem julgadas é melhor percebida nos relatos de L.L. e, sobretudo, de S.O., para quem "ser mãe é como viver um julgamento: é vc que não olha, é vc que não dá educação, é por tua causa que ele [o filho] é o que é”.

Diante desse cenário, ao falarem sobre suas vivências maternais particulares, essas mulheres podem estar construindo novas subjetividades ao inaugurarem, na concepção de Margareth Rago (1998; 2010), discursos que ajudam a quebrar as concepções impositivas, hierarquizantes e, não raramente, misóginas há tanto tempo consagradas como as únicas possibilidades existentes. No caso da maternidade, a visão de que é uma experiência integralmente prazerosa, gratificante e harmônica propagada inclusive por outras mães. 


\section{Pensamento Nietzschiano em face à maternidade}

Nietzsche (2009) entende a consciência (Gewissen) como autonomia, capacidade de empenhar a palavra e seguir querendo o que uma vez foi querido ou manter a resolução de deixar de querê-lo. A ideia de consciência não seria cativa da moral, e sim a potência de um trabalho sobre si. O filósofo, então, contrapõe os verbos sollen (dever) e wollen (querer) para apontar a existência de uma "memória da vontade", pela qual o indivíduo escolheria querer ou não querer algo, em vez de ser obrigado a não mais poder livrar-se de uma impressão certa vez inscrita; a memória da vontade, portanto, "não é entendida como prisão a marcas de um passado inexorável, não transformável” (FRANCO FERRAZ, 2016:31). Tal concepção seria capaz de curar o ressentimento na medida em que o sujeito empenha, com sua palavra, o seu desejo. Ou seja, promete. Ao fazê-lo, projeta-se no futuro. Tal projeção, ao contrário da memória construída pela mnemotécnica, não seria ligada a marcas, nem pesaria ao indivíduo. Essa cadeia do querer desemboca em uma corrente do desejo, na qual ocorre a transformação da vontade em tempo - que é o que permite que o indivíduo prometa.

O sujeito, por sua vez, não promete sem avaliar. Avaliar, para Nietzsche, difere de julgar. Enquanto o primeiro seria ligado à ética, o segundo estaria ligado à moral. O julgamento seria regido pela negatividade. Alguém subtrai do outro e disso extrai uma falsa legitimação de si. Ao apontar outrem como alguma coisa (por exemplo, uma mãe egoísta), o sujeito se afasta daquele termo, entendendo-se como não egoísta. Processo semelhante ao descrito por Santos \& Vaz (2017), quando o indivíduo elenca determinadas pessoas ou fatos em que deposita sua dor e os toma por seus causadores. Evita, assim, refletir sobre suas próprias crenças e posicionamentos. Já a avaliação não é isenta. Trata-se, para Nietzsche, de uma perspectiva que se anuncia como tal. Pode ser entendida como uma disposição dos critérios a partir dos quais o sujeito avalia. Ao contrário do julgamento, não implica ganhos. É uma colocação.

O filósofo defende que é preciso criar um homem capaz de prometer, responsável. Alguém que assuma o que quer, entenda seu entorno e os critérios que utiliza para avaliá-lo e, a partir disso, empenhe sua palavra para determinado fim. O indivíduo soberano seria "autônomo" e supramoral, já que autonomia e moralidade se excluem para Nietzsche. Esse indivíduo se livra da moral (estupidez, tirania). Não precisa do dever, pois já pode prometer. Ou seja, conquistou regularidade no querer. $\mathrm{O}$ responsável não é quem responde à lei (moral), mas quem empenha a palavra baseado em sua vontade, em direção ao futuro.

Assim, vivenciar - ruminar - as experiências em sua totalidade, inclusive os aspectos negativos, não apenas permite ao indivíduo se desprender desses acontecimentos e preparar-se para o novo, mas também desenvolve sua consciência acerca das próprias ações, tornando-o capaz de fazer promessas, senhor de si.

O comentário de S.C.B. pode ser associado a esse movimento. Diante das dificuldades de sua rotina - que ela reconhece e vivencia -, torna-se consciente sobre 
as escolhas maternais que pode fazer, avaliando-as como as melhores possíveis dentro de tais circunstâncias. "Me libertei, faço o melhor que posso", diz, ao explicitar um processo que se desprende da moral da devoção materna e sua consequente culpa.

\section{Pensamento Freudiano e suas modificações}

Freud (2010) argumenta que, para o estabelecimento das sociedades civilizadas, é preciso alocar a agressão. No cristianismo, na figura do Diabo; na Alemanha nazista, nos judeus. Forças precisam ser descarregadas. A impossibilidade de lidar com as ambiguidades humanas faria o homem projetá-las na forma de pecado em determinadas figuras. No caso da maternidade, a mãe egoísta, preguiçosa, amargurada.

A partir disso, indaga: de que recurso se vale a cultura para inibir, tornar inofensiva, talvez eliminar a agressividade que a defronta? A solução é internalizá-la, mandando-a de volta para o lugar de onde veio. Nesse ponto se aproxima de Nietzsche, para quem o homem é composto pela disputa de diferentes forças (que podem incluir a de agressão), cujas potências são distintas. A força mais potente resultará no comportamento ou ação empenhados pelo sujeito.

Uma vez introjetada, a agressividade seria acolhida por uma parte do "eu" que se contrapõe ao resto como Super-eu e que, de forma consciente, dispõe-se a exercer contra o "eu" a mesma agressividade que este gostaria de satisfazer em outros indivíduos. A consciência seria uma das funções atribuídas ao Super-eu, responsável por vigiar os atos e intenções do "eu" e julgá-los, exercendo uma atividade censória. Tal recriminação gera o sentimento de culpa, que é a percepção que o "eu" tem de estar sendo vigiado. A apreciação da tensão entre seus esforços e as exigências do Supereu, junto ao medo dessa instância crítica, gera a necessidade de castigo, expressão instintual do "eu" que, diante do Super-eu sádico, tornou-se masoquista, ou seja, "emprega uma parte do instinto para destruição interna nele presente para formar uma ligação erótica com o Super-eu" (2010: 109). A reação do "eu" ao sentimento de culpa seria o arrependimento.

Freud entende a culpa como moeda de troca do progresso. Ela estaria na origem da civilização, sendo incontornável àqueles que dela fizessem parte. Quando gera possibilidade de sublimação, pode ser aproveitada. Quando falha, gera neuroses que necessitam da intervenção da psicanálise. A consciência de culpa - expressão imediata do medo à autoridade externa e reconhecimento da tensão entre esta última e o "eu" - produzida pela cultura não é distinguida como tal, permanecendo inconsciente ou vindo à luz como um mal-estar, uma insatisfação para a qual se busca outras motivações. O paciente não percebe a culpa, o terapeuta é quem a esclarece. Desse modo, a culpa estaria no centro do problema do mal-estar, e é para ela que Freud busca tratamento.

Importante entender que, ao elaborar seus conceitos, Freud estava voltado para o homem do século XX de países europeus desenvolvidos. O psicanalista universalizou 
o sujeito masculino dessa época e localidade tendo em vista um fim - tratá-lo, livrálo do mal-estar advindo do projeto civilizador moderno. No entanto, a força dos elementos estruturais e normativos se alterou, estando muito abalada no século XXI.

As figuras de autoridade exploradas por Freud (o pai, o governo, a política) não têm mais o mesmo peso na vida dos indivíduos contemporâneos. Nesse sentido, o atual avanço de programas e ideologias de extrema direita, por exemplo, pode ser interpretado não como uma retomada de práticas modernas, mas como atos de resistência ao desmoronamento dessas estruturas. São entendidas como retrocessos, ou seja, anacrônicas, atrasadas, que não conduzem à novidade, mas ao que já foi feito. Portanto, o Super-eu de Freud exprime mais uma condição histórica do que uma chave fixa de entendimento sobre a psique contemporânea.

Hoje, o Super-eu freudiano poderia ser visto como o incômodo que alerta o indivíduo contra a procrastinação, a improdutividade que tanto se evita. Apesar de existir certa demanda por esse Super-ego repressivo e doutrinador, ela existe justamente por conta de seu enfraquecimento. O sujeito pensa menos em suas ações sob uma ótica punitiva, ou como um movimento interno. O que nos dias atuais configura-se como discurso de encorajamento - seja responsável, reflita sobre suas atitudes, exerça sua consciência - na época de Freud era entendido como comportamento rotineiro. Todavia, entre mães, a severidade para com os próprios atos permanece comum, sendo preciso que empreendam o esforço de se reconhecerem como passíveis de cometer falhas na relação com os filhos, conforme revela o comentário de C.N.: “(...) quando nossos filhos erram nos culpamos...e nos perguntamos: onde errei? mas ....somos humanos...”.

Efetua-se hoje uma estratégia persuasiva que apela para a liberação dos instintos vinculada a nichos de mercado, visando o consumo. Diferente das décadas de 20 e 30 em que havia uma contensão que Freud classificava como causadora do mal-estar - na contemporaneidade pratica-se o estímulo ao desejo e à excitação. Em um cenário em que "os sujeitos são instados a se construírem como empreendedores que exploram a si mesmos em sua condição de fontes de rendimento, sendo concebidos e gerenciados como "capital humano" (JORGE, 2015: 1), a "repressão" contemporânea é feita por estimulação, evocando os conceitos de desejo, afirmação e autorrealização. O controle se dá pelo gozo, não pelo castigo. Houve uma mudança na maneira como o indivíduo se cobra, na instância interna que move suas ações e desejos. O gozo é obrigatório. É preciso estar satisfeito e energizado porque o mais importante deixou de ser o bem coletivo, e sim o bem-estar individual (FRANCO FERRAZ, 2010; HEARN, 2017).

Assim, se existe um Super-eu contemporâneo, sua preocupação parece ser que reações a atitude do indivíduo provocará nos outros e como estas repercutirão em sua imagem. O comentário de L.L. alude a isso, quando se refere aos "palpites e comentários maldosos" vindos de outras mães. O maior castigo talvez seja justamente essa desvalorização (anulação, degradação) da própria imagem para o olhar alheio. Ou melhor, a falta de gozo diante da reação alheia a sua performance de si pode ser o sentimento contemporâneo que mais se aproxime da noção de castigo, capaz de gerar arrependimento. 
Paralelo a isso, desenrola-se uma alteração no modo de vivenciar as experiências. O processo nietzschiano de ruminar e digerir - que gera reflexão e renovação - vem sendo brecado pela influência do capitalismo e de práticas corporativistas, pelo imediatismo midiático e do consumo. Evita-se ter contato duradouro e profundo com experiências difíceis, que causam dor. É mais cômodo transferir a responsabilidade para outro, torná-lo a causa do problema enfrentado (FRANCO FERRAZ, 2010).

Nesse cenário, a exteriorização da agressividade parece mais liberada. Se o esforço moderno era justamente vertê-la para dentro do sujeito - internalizá-la, colocando-a no espaço habitado por sua subjetividade - os SRSs constituem espaços em que os indivíduos podem extravasar sua agressividade, elegendo figuras (tal qual o Diabo para o cristianismo e os judeus para os nazistas) que possam comportar o mal, o incômodo e demais fatores contra os quais se posicionam. Se a subjetividade contemporânea se constrói externamente, é para o exterior que sua agressão será deslocada, como acontece na publicação "SÓ BISERVANDO”. Em vez de se torturar por não seguir determinada maternagem, Lucinha posta um texto em que critica certas "blogueiras de maternidade" por propagarem uma rotina que considera impraticável para a maioria das mães, tornando-as alvo de sua ironia e deboche.

\section{A vergonha como valor, a narrativa como recurso}

Corroborando o pensamento de Nietzsche (2009) de que o sentido é fluido e altera-se conforme diferentes épocas e contextos, em muitas manifestações contemporâneas a culpa aparece mais associada ao mecanismo da vergonha do que ao do castigo.

A noção de culpa e os dilemas que envolve têm a ver com a dinâmica na qual a interioridade desempenha um papel central, enquanto a ideia da vergonha como ordenadora imaginária das relações dos indivíduos se associa ao olhar de aceitação ou de recusa, de reconhecimento ou não reconhecimento que o indivíduo busca na exposição pública de si. Isso se relaciona não apenas à relevância da imagem do corpo, da performance física, mas, sobretudo, à visibilidade. Esta tornou-se um fator com uma importância no agenciamento da vida subjetiva que não possuía antes que o mundo fosse tão atravessado por práticas de visibilização. Constitui um traço diferente, recente, dos mecanismos por meio dos quais indivíduos biológicos vão se tornando sujeitos (BEZERRA JUNIOR, 2017).

As mudanças nas experiências do espaço e do tempo aceleram-se de tal modo que fazem com que a prática da interioridade conflitiva, reflexiva - que cria um sentimento de que aquilo que o sujeito é encontra-se dentro de si (cabendo a ele revelá-lo ou não) - ainda exista, mas apareça ao lado de uma enorme quantidade de elementos que se relacionam com um novo ambiente. Nessa nova atmosfera, aquilo que os outros veem do indivíduo e o que acham dele - seja ao vivo ou nos SRSs - é muito relevante (ibid). Assim, o constrangimento diante do olhar alheio ganha novas 
dimensões, transformando a vergonha naquilo que o indivíduo busca evitar. Isso evidencia o deslocamento das questões mais fundantes inscritas na relação do sujeito consigo mesmo para um tipo de dinâmica em que aquilo que circula a seu respeito e o que ele projeta têm papel crucial na valorização do sentimento de si.

Contudo, a vergonha não foi o sentimento priorizado pelas mães em seus relatos, e sim a culpa. Uma delas, L.L., chega a colocá-la como inevitável na atividade materna. Apesar disso, alguns indícios apontam que essas mães escreveram seus comentários tendo a consciência de estar sendo lidas - e possivelmente avaliadas ou julgadas - pelas demais participantes da discussão. As descrições extensas que S.C.B. e A.R. fazem de suas rotinas, por exemplo, mais do que explicar por que aquelas práticas são o melhor que pode fazer (S.C.B.) ou por que está tão cansada (A.R.), parecem prevenir possíveis críticas sobre a maternagem que praticam, o amor que nutrem pelos filhos, entre outros pontos que pudessem ser questionados. A narrativa de A.R. chega a dizer que não faz distinção entre os filhos "porque ama os dois por igual" e conta, inclusive, com uma observação de encerramento: "mesmo tão cansada de tudo agradeço a Deus todos os dias por ter eles comigo aqui”. Para além de uma demonstração genuína de afeto pelos filhos, é possível pensar que também se trate de um recurso discursivo apaziguador, alinhado à gratidão e ao carinho que tradicionalmente se esperam do comportamento materno. Ao exporem seus sentimentos e rotinas em um ambiente público, as autoras mostram-se preocupadas com as possíveis impressões que causam, talvez cientes de que, como coloca Fernanda Bruno (2013), as redes de visibilidade e de controle muitas vezes se sobreponham.

\section{Digerindo a maternidade}

A culpa que desde o final do século XVIII acompanha a vivência materna permanece presente nas narrativas construídas por mães contemporâneas. Boa parte das reflexões são relativas ao que sentem e fazem, como lidam com a maternidade em termos individuais. No entanto, ao expor seus obstáculos, algumas críticas se dirigem a outros, como "as mães que se acham perfeitas" (L.L.) e aqueles que transformam as atitudes maternas em um "julgamento" (S.O.), eleitos para representar a causa de seus problemas com relação ao exercício maternal. É possível associar esses desabafos ao fenômeno contemporâneo descrito por Santos \& Vaz (2017). Ao apontar culpados para seu sofrimento, colocando-se na posição de vítimas, essas mães estariam atribuindo a responsabilidade - e, consequentemente, a solução - das dificuldades que vivenciam a terceiros, afastando-se da culpa e da vergonha pela situação que desaprovam. Assim, sua agressividade é dirigida para esses “inimigos”, em vez de para si mesmas.

Todavia, é possível pensar que façam mais do que se colocar na posição de vítimas, sobretudo porque não estão simplesmente transferindo a responsabilidade pelas frustrações maternais. Apontam elementos que contribuem para essa 
problemática, ao mesmo tempo em que colocam suas atitudes e discursos como agentes transformadores dessa realidade. Assumem o sentimento de culpa, porém o percebem como negativo, injusto. Em última instância, falar da culpa revela-se um modo de se afastar dela e, por conseguinte, da imagem da mãe infalível, reconhecendo suas limitações na maternagem sem que isso equivalha a se classificarem como mães incapazes. Nas palavras de M.M., "é a vida, não somos perfeitas". Aproximam-se, nesse ponto, da capacidade de construção de narrativas paralelas e mesmo opostas ao discurso dominante, tal como defendido por Rago (1998).

Além disso, os relatos não negam nem se desvencilham dos desafios da maternidade. Isto é, não evitam o contato com aquilo que é desagradável e doloroso prática contemporânea cada vez mais comum. Pelo contrário, estão detalhando essas dificuldades, destacando-as. O comentário de R.V.U. conta que ficou acordada até tarde da noite por causa da filha e, depois de ter insônia, foi dormir "quase 2 da manhã com a cabeça cheia de preocupações”; dizendo estar cansada, A.R. compartilha que passa o dia inteiro "arrumando a casa, limpando bb, ensinando o maior a ler"; M.G. descreve a maternidade como uma "árdua caminhada".

Diante disso, poder-se-ia entender a escrita sobre os obstáculos da maternidade como uma ruminação? Afinal, essas mulheres não fogem ao desconforto das experiências negativas da vivência maternal, como seria possível pensar sob a ótica de Santos \& Vaz (2017). Elas as vivenciam a ponto de perceberem que emoções desencadeiam e como se inserem no quadro maior da cultura e da sociedade à qual pertencem. Reconhecer e falar sobre a dor dessas experiências seria uma maneira de processá-las. Mas, se a ruminação nietzschiana é internalizada, refletindo a prática moderna de construção subjetiva, a ruminação contemporânea dá-se no espaço público, diante do olhar alheio, desejosa de interação.

Em muitos aspectos, tal analogia se sustenta. O compartilhamento da dificuldade em superar a culpa materna é uma intenção muito presente nos relatos que, em diálogo uns com os outros, ruminam a experiência da maternidade, configurando um processo cujas modificações são particulares - realizadas nas ações e pensamentos de cada mãe que narra seus estorvos e/ou lê os comentários alheios -, mas cujo desenrolar é coletivo, advindo de um espaço público em que são trocadas vivências pessoais. Digerir aquilo que se vive é necessário para ser capaz de esquecer e, com isso, seguir em frente sem apego ou mágoa.

Apesar de reconhecerem a culpa, as mães procuram amenizá-la por meio da descrição do quanto é complicado dar conta de todas as exigências maternais, como na narrativa de M.M., em referência à "pregação da comida saudável, não gritar, não bater”. O comentário de A.R. realiza movimento parecido ao descrever os muitos afazeres de sua rotina, mas, além da tentativa de superação da culpa, outro sentimento se destaca: o ressentimento. "Queria poder tomar banho demorado sem medo do bb chorar (...). Queria arrumar meu cabelo que cresceu 5 dedos metade enrolada e metade lisa”, lamenta a autora. Essas frustrações ainda a afetam, não foi capaz de se libertar completamente delas. 
O ressentimento também aparece nas narrativas de T.V. ("Acho que nunca tive tempo de ser mãe dessa maneira. Agora vejo, infelizmente") e T.A. (“eu só queria poder ser gente às vezes"), ao se queixarem, respectivamente, de arranjos do passado que, por isso, não são mais transformáveis e da situação que a autora vive e acredita não conseguir mudar. Mas é no comentário de M.S. que o ressentimento ganha mais força: “ (...) damos nossas vidas por nossos filhos, mas depois crescem e esquecem que têm mãe, não fazem nem metade do que fizemos por eles”, escreve. Sua projeção no futuro, bem como a de T.V. e T.A., reproduz aquilo que desgosta em seu cotidiano, impossibilitando-a de vivê-lo plenamente, e, ainda, prendendo-a a um passado que enxerga como fadado a se repetir - não porque assim deseja, mas por acreditar que seu querer não basta para dar outro rumo à situação. Já C.N. demonstra dificuldade em esquecer, afirmando perguntar-se onde errou quando os filhos cometem erros. Isso lhe causa sofrimento, pois não consegue se libertar da autocobrança que a impede de se abrir a novas possibilidades com os filhos e projetar-se em um futuro em que não se obrigasse a se culpar pelos erros deles.

Interessante perceber que, no relato de R.V.U., o esquecimento - conceito tão caro a Nietzsche - é interpretado como negativo, associado à culpa. A autora não esqueceu no sentido de processar para posteriormente superar um evento ruim, nem deixou de se intimidar pelas preocupações maternais. Ela esqueceu de levar o maiô para a filha no "dia de piscina", e se disse "arrasada” por isso. Ainda assim, pode-se pensar que esse processo abra caminho para a digestão, tanto da experiência de deixar o maiô em casa quanto do impacto que tal falha teve sobre a mãe, permitindo que, em algum momento, deixe essa culpa para trás. O próprio modo como o comentário é escrito subentende a tentativa de ressignificar o deslize materno menos como um trauma e mais como algo que teve razões justificáveis para acontecer. "Foi bom ler esse texto", compartilha R.V.U., indicando que o contato com narrativas de outras mães sobre a culpa materna - e a interação com elas - é um aspecto relevante nesse empreendimento.

Já no comentário de S.X., a memória aparece como capaz de causar culpa à autora, quando lembra que "poderia ter tido mais paciência, ter dado mais colo, mais abraços e ter evitado umas palmadas por motivos bobos". Aliada ao sofrimento, aproxima-se da concepção nietzschiana de ser um entrave que suspende o esquecimento e impede que o sujeito se livre do que o incomoda. No caso, a culpa materna.

Combatê-la é o objetivo da maioria das narrativas, processo que se dá na coletividade, com o apoio de outras mães. O comentário de C.F. é bastante ilustrativo desse movimento, ao agradecer à autora da postagem "SÓ BISERVANDO": "Te amo Lucinha, porque quando estou me sentindo a pior mãe do mundo, quando perco a paciência com a cria e grito, brigo e logo depois me sinto culpada e menos mãe, vem vc com seus textos e me faz sentir gente novamente". A repercussão de tais narrativas nas mães que com elas interagem não se dá apenas em relação à maternidade, mas à sua autoestima e ao modo como enxergam a si mesmas - elementos constitutivos de suas subjetividades. 


\section{Considerações finais}

Diante da importância que o reconhecimento alheio passa a ter na construção subjetiva contemporânea, é possível interpretar a vergonha como resultado da frustração de expectativas criadas sobre o olhar do outro. Ao fazer uma exposição no caso, ao relatar suas experiências maternais - busca-se certo efeito (de valoração, reflexão, empatia) por parte de outrem, não a indiferença ou o desprezo. Sobretudo, espera-se ser visto por um determinado público, que interessa a quem se expõe.

Foi o que as autoras dos relatos sobre a maternidade alcançaram ao ter seus comentários curtidos e respondidos por outras mulheres e/ou mães. Muitas vezes, era a essas interlocutoras potenciais a quem seus relatos se dirigiam, buscando não apenas a problematização da culpa materna, mas também amparo.

Se nos séculos XIX e XX a agressividade era internalizada porque se acreditava que sua exteriorização seria danosa à sociedade, na era contemporânea ela é externalizada por se entender que sua interiorização será prejudicial ao indivíduo. Ele é o fator a ser preservado, enquanto o ambiente externo - onde expõe inclusive o que não gosta - serve à criação de sua identidade. A agressividade aparece deslocada para o mesmo âmbito em que a subjetividade se constrói em cada época. No caso dos relatos sobre as vivências maternais, essa agressividade pode ser compreendida como as queixas, desabafos e declarações de insatisfação, cansaço ou raiva a determinados aspectos da maternidade e/ou ao tratamento a ela dispensado.

Apesar de apontarem alguns culpados por reforçarem as situações que desaprovam na experiência materna - atribuindo-lhes responsabilidade por elas -, as autoras das narrativas não se limitam ao papel de vítimas de uma determinada estrutura. Compartilham a consciência de como esta última opera e de que sua ação individual pode modificar sua lógica. Sobretudo, dividem a responsabilidade de criar novas experiências maternais, reconhecendo seu papel (de afirmação ou transformação; acatamento ou mudança) dentro das dinâmicas que criticam.

O sentimento de culpa, ainda que existente, é percebido como equivocado. Por meio de seus relatos, procuram combatê-lo, preferindo atuar para a modificação da maternidade do que se reprimirem por não serem mães boas o bastante - ou seja, a punição do Super-eu freudiano perde força diante da possibilidade de ação. Colocamse enquanto possíveis agentes modificadoras de um contexto que, apesar de não ter sido criado por elas, pode ter contado com seu apoio ou indiferença em algum momento.

A imposição contemporânea pela satisfação constante pode tornar os desafios da maternidade mais frustradores, tanto que algumas mães se declaram muito abaladas por não corresponderem a determinadas expectativas. Porém, mesmo voltados ao objetivo de tornar a maternidade menos dolorosa, os relatos não rechaçam a raiva, a tristeza e o desgosto causados por essa decepção. Segundo Nietzsche, estar vivo dói. Para viver com plenitude, é necessário abraçar essa dor - sem se apegar ao sofrimento que causa.

Se o esquecimento não é o oposto da memória e sim uma liberação, ao processar as experiências é possível libertar-se delas. Quem esquece é capaz de se 
livrar de fórmulas antigas para adotar novas práticas. Enquanto ainda se ressentem pelas imposições e sacrifícios maternos, as autoras das narrativas não são capazes de digerir completamente a experiência de maternidade. Talvez por isso alguns discursos soem rancorosos. Ao trazerem à tona vivências que, na verdade, não tinham esquecido porque até então não haviam refletido sobre elas, essas mulheres podem ruminá-las até ser possível pensar para além delas.

Com isso, ficam mais aptas a se liberarem da culpa, da moral materna e da vergonha, aproximando-se da concepção nietzschiana de responsabilidade. Deixam de julgar o contexto em que se inserem e passam a avaliá-lo, com base em critérios que explicitam. Assim, tornam-se capazes de prometer - ao se projetarem no futuro - repensar a experiência maternal por meio de suas ações e discursos, possibilitando, talvez, o surgimento de novas maneiras de lidar com as mães, a maternagem e a própria maternidade.

\section{Referências}

AGAMBEN, Giorgio. (2009). O que é contemporâneo? e outros ensaios. Chapecó, SC: Argos.

BADINTER, Elisabeth. (2011). O conflito: a mulher e a mãe. Rio de Janeiro: Record. (1985). Um amor conquistado: o mito do amor materno. São Paulo: Nova Fronteira.

BEZERRA JUNIOR, Benilton. (2014). As novas fronteiras da subjetivação. Percy Reflexão, 23 set. Disponível em: <https://www.youtube.com/ watch?v=qOGhiov_1pM>. Acesso em: 16 jun. 2018.

(2017). Interioridade: Culpa e Vergonha. Narciso 21, 27 maio. Disponível em: <https://www.youtube.com/watch?v=c6WJKwezuqU>. Acesso em: 16 jun. 2018.

BRUNO, Fernanda. (2013). Máquinas de ver, modos de ser: vigilância, tecnologia e subjetividade. Porto Alegre: Sulina.

COSTA, Jurandir Freire. (1999). Ordem médica e norma familiar. Rio de Janeiro: Edições Graal.

FOUCAULT, Michel. (1983). Vigiar e Punir. Petrópolis: Vozes.

FRAGOSO, Suely; RECUERO, Raquel; AMARAL, Adriana. (2011). Métodos de pesquisa para Internet. Porto Alegre: Editora Sulina. 
FRANCO FERRAZ, Maria Cristina. (2010). Homo deletabilis: corpo, percepção, esquecimento do século XIX ao XXI. Rio de Janeiro: Garamond.

. (2016). "Memória e esquecimento no final do século XIX: Bergson e Nietzsche". In: C. Negreiros; F. Oliveira \& R. Gens (orgs.), Belle époque: crítica, arte e cultura. Rio de Janeiro: Intermeios. p. 17-34.

FREIRE, Maria Martha de Luna. (2009). Mulheres, mães e médicos: discurso maternalista no Brasil. Rio de Janeiro: Editora FGV.

FREUD, Sigmund. (2010). O mal-estar na civilização, novas conferências introdutórias e outros textos (1930-1936). São Paulo: Companhia das Letras.

(1976). "Feminilidade". In: Edição standard brasileira das obras psicológicas completas de Sigmund Freud, vol. 22. Rio de Janeiro: Imago. p. 139-165.

HEARN, Alison. (2017). "Verified: Self-presentation, identity management, and selfhood in the age of big data”. Popular Communication, v. 15, n. 2, p. 62-77.

JORGE, Marianna Ferreira. (2015). "Narrativas da (in)felicidade: Medicalização da vida e espírito empresarial na sociedade contemporânea”. In: COMUNICON, X, São Paulo. Anais eletrônicos... São Paulo. Disponível em: <http://docplayer.com.br/59199256Narrativas-da-in-felicidade-medicalizacao-da-vida-e-espirito-empresarial-na-sociedadecontemporanea-1.html>. Acesso em: 15 jun. 2018.

KING, Vera. (2016). "If you show your real face, you'll lose 10 ooo followers - The Gaze of the Other and Transformations of Shame in Digitalized Relationships". Communication and Media, v.11, n.38, p.71-90.

LOSSO, Renata. (2011). Filósofa francesa critica o mito da mãe perfeita em novo livro. Delas. Disponível em: <http://delas.ig.com.br/filhos/filosofa-francesa-criticao-mito-da-mae-perfeita-em-novo-livro/n159699742670o.html>. Acesso em: 15 jun. 2018.

NIETZSCHE, Friedrich. (2009). Genealogia da Moral. São Paulo: Companhia das Letras.

PEDRO, Joana Maria. (1998). “A publicidade na intimidade: punição e controle”. In: M.P. Grossi \& __ (orgs.), Masculino, feminino, plural: gênero na interdisciplinaridade, Florianópolis, Editora Mulheres. p.273-292.

POLIVANOV, Beatriz. (2014). Dinâmicas Identitárias em Sites de Redes Sociais: Estudo com Participantes de Cenas de Música Eletrônica no Facebook. Rio de Janeiro: Luminária. 
RAGO, Margareth. (2010). "Cartografias de si no feminismo da diferença: Amelinha, Gabriela, Norma”. Gênero, v.10, n.2, p. 151-175. Disponível em: <http://www. revistagenero.uff.br/index.php/revistagenero/article/view/22/10>. Acesso em: 15 jun. 2018.

(1998). "Epistemologia feminista, gênero e história". In: M. P. Grossi \& J. M. Pedro (orgs.), Masculino, feminino, plural: gênero na interdisciplinaridade, Florianópolis, Editora Mulheres. p. 21-41.

SIBILIA, Paula. (2015). "O universo doméstico na era da extimidade: Nas artes, nas mídias e na internet”. Revista Eco Pós, v.8, n.1, p. 132-147.

. (2016). O show do Eu: A intimidade como espetáculo. 2. ed. Rio de Janeiro:

Contraponto.

SANTOS, Amanda; VAZ, Paulo. (2017). "Trauma, Identidade e Testemunho: Deslocamentos conceituais e a construção da subjetividade contemporânea". In: COMPÓS, XXVI, São Paulo. Anais eletrônicos...São Paulo. Disponível em: <http:// www.compos.org.br/anais_encontros.php>. Acesso em: 16 jun. 2018.

Recebido: 22.12.2017

Aceito: 30.05 .2018 